\title{
Surgical treatment of vertebral body comminuted fractures
}

\author{
V.V. Zaretskov, V.B. Arsenievich, Sergey V. Likhachev, L.A. Artemov, Yu.I. Titova and D.P. Zueva \\ Saratov Scientific Research Institute of Traumatology and Orthopedics
}

Accepted 23 July 2012

Original Text in Russian (C) Zaretskov VV, Arsenievich VB, Likhachev SV, Artemov LA, Titova Yul, Zueva DP, 2011, published in Saratov Journal of Medical Scientific Research 2011; 7(1): 146-147.

Abstract: The given report concerns the method of surgical treatment of vertebral body comminuted fractures. The surgery is presented by transpedicular fixation of an injured part and allows reduction of injured vertebra body fragments. Simplicity of its technical operation and the technique efficiency confirms its practical value.

Keywords: vertebral body comminuted fractures, transpedicular system, diaplasis.

Cite as Zaretskov VV, Arsenievich VB, Likhachev SV, Artemov LA, Titova Yul, Zueva DP. Surgical treatment of vertebral body comminuted fractures. Russian Open Medical Journal 2012; 1: 0209.

Correspondence to Sergey V. Likhachev. Address: 148, Chernishevsky str., Saratov, 410002, Russia. Phone: +7 (8452) 233859. E-mail: Likha4@mail.ru

Among all orthopedic traumas the amount of backbone injuries comes up to $17,7 \%$. Such injuries are from the category of the severest traumas, the most of the injured become disabled for a long period of time [1]. Over the last years surgical methods are getting more popular in backbone injuries treatment [2]. These methods, as usual, let patients get rid of a long bed rest and give a chance to achieve full functional rehabilitation [3]. Transpedicular fixation system [4] is widely brought to use in unstable thoracic spine and lumber spine injuries (it is often vertebral body comminuted fractures).

If an injured vertebral body diastasis hinders bony union, increases secondary fragment dislocation risk, and also interrupts bony tissue trophic, it is entirely possible that there can be some complications in transpedicular fixation: posttraumatic osteonecrosis (Kummel disease), false joint formation and posttraumatic pathological kyphosis recurrence. At the same time there is A.A. Afaunov, V.D. Usikov and V.V. Usikov's techniques focused on problem solution [5]. This is the method of transpedicular fixation of injured and intact approximal vertebrae. Then bone screws are administered into the injured vertebral body through its vertebral arch roots which reduces secondary fragment dislocation risk. Nevertheless using this method it is impossible to use reduction of injured vertebra body fragments.

Therefore we suggested "Reduction of spinal comminuted fractures method" and a useful model for realization [7].

The principle of the method is that transpedicular bone screws are administered into spondyles adjacent to an injured one under $\mathrm{C}$-arm control. The surgery in the affected part of a spine is performed through a posterior approach. Then bone thread cutter 2 (Figure 1a) is administered into a ventral fragment1 of an injured vertebra (Figure 1). During the passage of the bone thread cutter in horizontal plane declivity angles should be kept: $5-10^{\circ}$ is for lower thoracic spine, $15^{\circ}$ is for lumber spine. There is no further advance of a bone thread cutter behind 2 ventral fragment 1 vertebral cortical rim because of a dynamic limiter 3 . Next, keeping on twisting a bone thread cutter 2, dynamic compression is produced which is important for ventral fragment reposition 1 (Figure 1b). After that through the Roy-Kamilla contralateral point 4 (Figure 1b) and a channel formed by bone thread cutter the bone screw 5 is administered. The bone screw fixes reduced ventral fragment 1 (Figure 1c). Then bone thread cutter should be removed 2 and another bone screw is administered into a channel 6 (Figure 1d). After all these procedures are performed a complete transpedicular system mounting should be made.

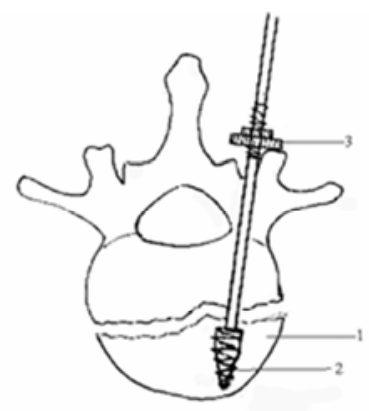

A

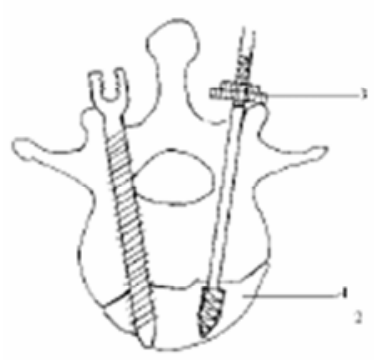

C

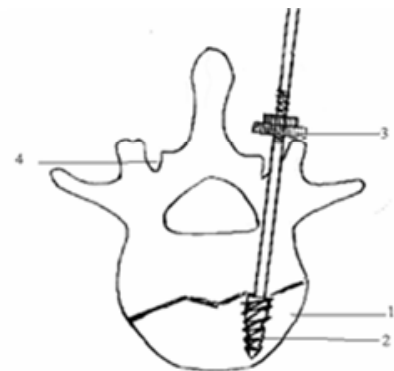

B

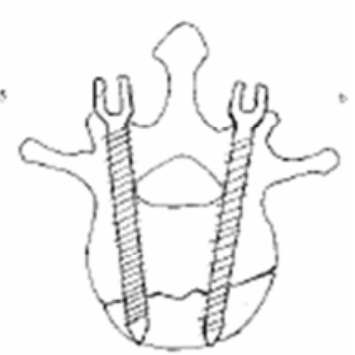

D
Fig. 1. Stages of spondyle fragments fixation in vertebral body comminuted fractures. 


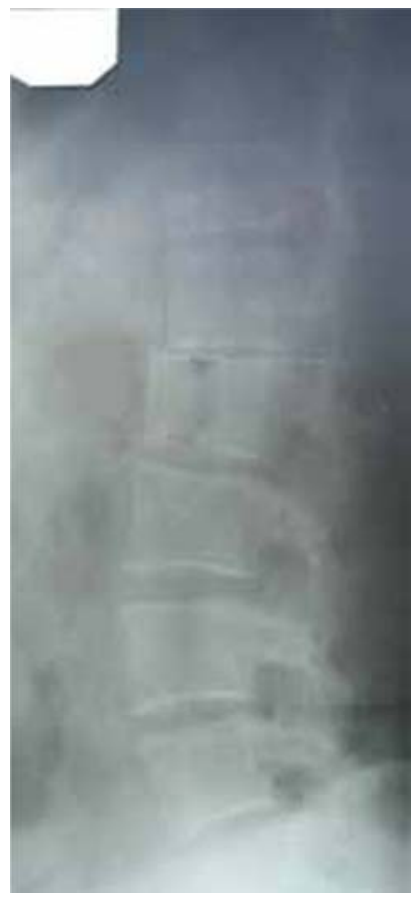

A

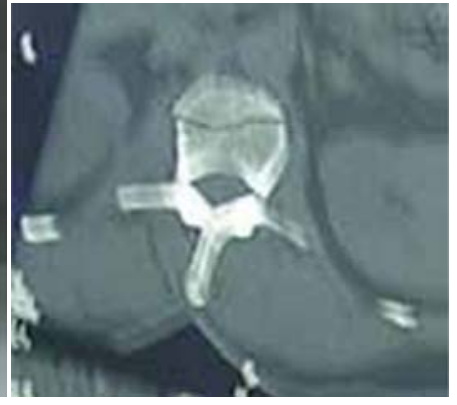

B
Fig. 2. X-ray image of the patient R.: lateral view before surgery (a); the same patient's L1 spondyle CT before surgery (b).

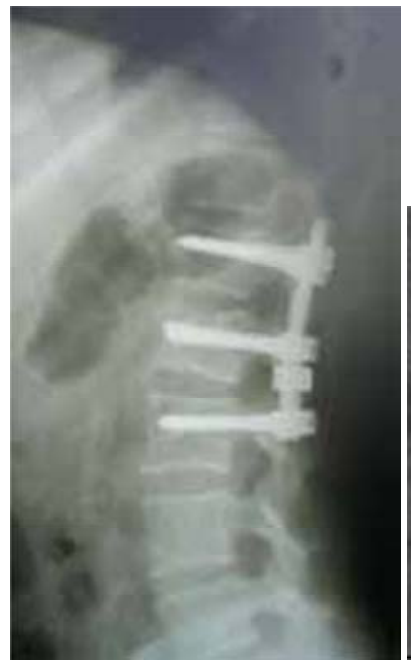

A

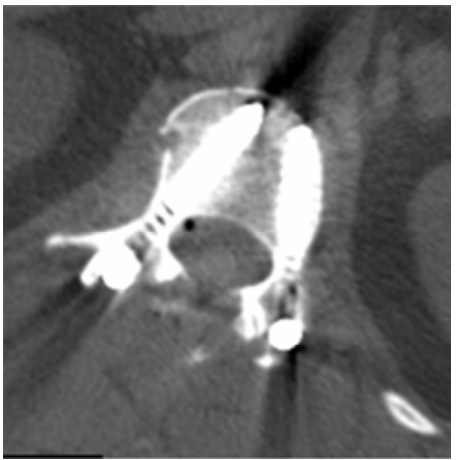

B
Fig. 3. X-ray image of the patient R.: lateral view after surgical treatment (a); the same patient's L1 spondyle CT after surgical treatment (b).

\section{Clinical event}

A female patient R. of 1954 has checked into a department of traumatology and orthopedics for a closed uncomplicated lumbar spine injury. The patient fell 2 meters down on her back. During an $X$-ray imaging the $L_{1}$ vertebral body compression and comminuted fracture (Figure 2a) has been revealed. A fracture line crossed upper and lower endplates (type A in F. Denis classification), and as a result big vertebral body ventral fragment formed (Figure $2 b$ ). Because of the revealed pathology there was a surgical treatment using the suggested method. After posterior surgical approach there have been by two bone screws administered into $T h_{12}$ and $L_{2}$ spondyles. Then the bone thread cutter has been administered from the left into $L_{1}$ vertebral body ventral fragment. The bone thread cutter limiter is fixed up at an equal distance to linear dimension of a vertebral body from neural arch root of vertebra to ventral cortical rim. Next under C-arm control dynamic compression successive bone thread cutter twisting is performed until ventral fragment reposition is done. The bone screw is administered through the Roy-Kamilla contralateral point. It fixes ventral fragment reduced. The bone thread cutter is removed and another bone screw is administered into a channel. A complete transpedicular system mounting is performed.

During control observing implanted system was stable, there was no pathological kyphosis, spinal canal was intact (Figures 3a and $3 \mathrm{~b}$ ). Postoperative period is unremarkable, healing by primary intention. After 2 weeks the patient is discharged from hospital in satisfactory condition under the care of traumatologist.

\section{Conclusion}

Simplicity of its technical operation and the technique efficiency in surgical treatment of vertebral body comminuted fractures makes it possible for practical use.

\section{Reference}

1. Gaidar BV. Khirurgicheskoe lechenie patsientov s povrezhdeniyami pozvonochnika grudnoi i poyasnichnoi lokalizatsii [Surgical treatment in patients with thoracic and lumbar spine injuries]. Khirurgiya pozvonochnika 2004; 3: 40-45.

2. Zaretskov VV. Khirurgicheskoe lechenie povrezhdeniy i zabolevaniy pozvonochnika: prakticheskoe rukovodstvo dlya vrachei [Spinal injuries and diseases surgical treatment: practice guidelines]. Rybinsk, Rybinsk Dom pechati, 2007, $112 \mathrm{p}$.

3. Ramikh EA, Atamanenko MT. Khirurgicheskiye metody v komplekse lecheniya povrezhdeniy grudnogo i poyasnichnogo otdelov pozvonochnika [Thoracic and lumbar spine injuries complex surgical treatment]. Vestnik travmatologii i ortopedii im. N.N. Priorova, 2003, no. 3, pp. 43-48.

4. Polishchuk NE, Korzh NA, Fishchenko VYa. Povrezhdeniya pozvonochnika i spinnogo mozga (mekhanizmy, klinika, diagnostika, lechenie) [Spinal and spinal cord injuries (mechanisms, clinics, diagnostics, treatment)]. Kiev, Kniga plus, 2001, 388 p.

5. Patent (Rus) no. 2002122054: Spinal reposition method in comminuted fractures and fracture dislocation.

6. Patent (Rus) no. 2010121609: Spinal reposition and fixation method in comminuted fractures.

7. Patent (Rus) no. 2010121599: Bone thread cutter for vertebral body fragments reposition.

\section{Authors (2011 year):}

V.V. Zaretskov - MD, D.Sc., Leading Researcher, Department of New Technologies in Vertebrology and Neurosurgery, Saratov Scientific Research Institute of Traumatology and Orthopedics, Saratov, Russia;

V.B. Arsenievich - MD, PhD, Head of Department of Traumatology and Orthopedics,Saratov Scientific Research Institute of Traumatology and Orthopedics, Saratov, Russia;

Sergey V. Likhachev - MD, Attending Physician, Saratov Scientific Research Institute of Traumatology and Orthopedics, Saratov, Russia;

L.A. Artemov - MD, Attending Physician, Saratov Scientific Research Institute of Traumatology and Orthopedics, Saratov, Russia;

Yu.I. Titova - MD, Radiologist, Saratov Scientific Research Institute of Traumatology and Orthopedics, Saratov, Russia;

D.P. Zueva - MD, PhD, Scientific Assistant, Department of New Technologies in Vertebrology and Neurosurgery, Saratov Scientific Research Institute of Traumatology and Orthopedics, Saratov, Russia. 